\title{
FETC Programs for Reducing Greenhouse Gas Emissions
}

John A. Ruether

February 1998

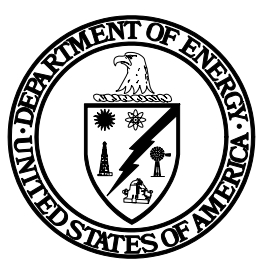

\author{
U.S. Department of Energy
}

Federal Energy Technology Center

Pittsburgh, Pennsylvania

Morgantown, West Virginia

FETC's Customer Service Line: (800) 553-7681

FETC's Homepage: http://www.fetc.doe.gov/ 


\section{Disclaimer}

This report was prepared as an account of work sponsored by an agency of the United States Government. Neither the United States Government nor any agency thereof, nor any of their employees, makes any warranty, express or implied, or assumes any legal liability or responsibility for the accuracy, completeness, or usefulness of any information, apparatus, product, or process disclosed, or represents that its use would not infringe privately owned rights. Reference herein to any specific commercial product, process, or service by trade name, trademark, manufacturer, or otherwise does not necessarily constitute or imply its endorsement, recommendation, or favoring by the United States Government or any agency thereof. The views and opinions of authors expressed herein do not necessarily state or reflect those of the United States Government or any agency thereof.

Available to DOE and DOE contractors from the Office of Scientific and Technical Information, P.O. Box 62, 175 Oak Ridge Turnpike, Oak Ridge, TN 37831; prices available at (423) 5768401, fax — (423)576-5725, E-mail — reports@adonis.osti.gov

Available to the public from the National Technical Information Service, U.S. Department of Commerce, 5285 Port Royal Road, Springfield, VA 22161; phone orders accepted at (703) 4874650 . 


\section{Contents}

Page

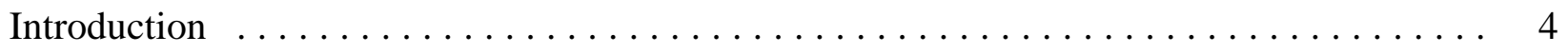

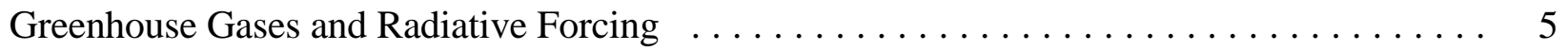

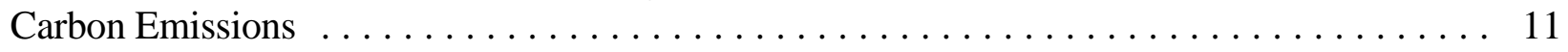

$\mathrm{CO}_{2}$ Emissions Arising From Human Activities $\ldots \ldots \ldots \ldots \ldots \ldots \ldots \ldots \ldots$

Energy Intensity of the GDP and Carbon Intensity of Energy $\ldots \ldots \ldots \ldots \ldots 11$

FETC Programs to Reduce Greeenhouse Gas Emissions $\ldots \ldots \ldots \ldots \ldots \ldots \ldots \ldots$

Increasing Energy Efficiency (reducing E/GDP) $\ldots \ldots \ldots \ldots \ldots \ldots \ldots \ldots$

Decreasing Carbon Intensity of Energy (reducing $\mathrm{Cg} / \mathrm{E}$ ) $\ldots \ldots \ldots \ldots \ldots \ldots$

Increased Use of Natural Gas for Power Generation $\ldots \ldots \ldots \ldots \ldots 13$

Co-Firing Biomass and Coal $\ldots \ldots \ldots \ldots \ldots \ldots \ldots \ldots \ldots \ldots \ldots$

Production of Liquid Hydrocarbon Fuels From Remote Natural Gas . . . . 15

Increasing $S$ (enhancing natural sinks and creating synthetic sinks) $\ldots \ldots \ldots \ldots \quad 16$

Deep Subterranean Injection of $\mathrm{CO}_{2} \quad \ldots \ldots \ldots \ldots \ldots \ldots \ldots \ldots \ldots$

Injection of $\mathrm{CO}_{2}$ Into Deep Coal Seams $\ldots \ldots \ldots \ldots \ldots \ldots \ldots \ldots \ldots \ldots \ldots$

Deep Sea Injection of $\mathrm{CO}_{2} \ldots \ldots \ldots \ldots \ldots \ldots \ldots \ldots \ldots \ldots \ldots$

Retrofitting Existing Coal-Fired boilers for Use of Oxygen Instead of Air . . 18

Coal Mine Methane Capture and Use . ................ 18

Engineering Data Base for Collection, Transportation, and Sequestration

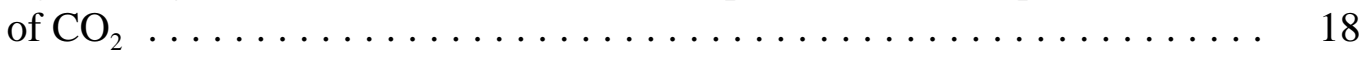

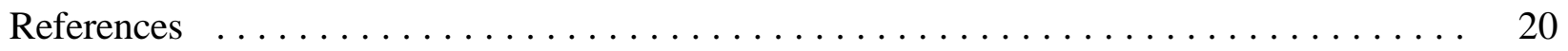

\section{List of Figures}

Figure $1 \quad$ Blackbody Curves for $6,000 \mathrm{~K}$ and $255 \mathrm{~K} \ldots \ldots \ldots \ldots \ldots \ldots$

Figure 2 Emission Spectrum at the Tropopause $\ldots \ldots \ldots \ldots \ldots \ldots \ldots \ldots . . \ldots$

Figure 3 Relative Contributions to Radiative Forcing of Some Greenhouse Gases … 10

\section{List of Tables}

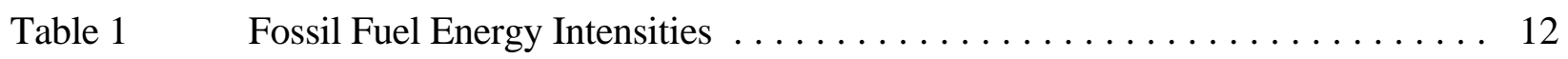

Table 2 Thermal Efficiencies of Some Modern Fossil-Based Power Systems . . . . . 14 


\section{Introduction}

Mark Twain once quipped that everyone talks about the weather but no one does anything about it. With interest in global climate change on the rise, researchers in the fossil-energy sector are feeling the heat to provide new technology to permit continued use of fossil fuels but with reduced emissions of so-called "greenhouse gases."

Three important greenhouse gases, carbon dioxide, methane, and nitrous oxide, are released to the atmosphere in the course of recovering and combusting fossil fuels. Their importance for trapping radiation, called forcing, is in the order given. In this report, we briefly review how greenhouse gases cause forcing and why this has a warming effect on the Earth's atmosphere. Then we discuss programs underway at FETC that are aimed at reducing emissions of methane and carbon dioxide. 


\section{Greenhouse Gases and Radiative Forcing}

\section{Greenhouse Gases Trap Radiant Energy}

There are two sources of radiant energy that are important to warming Earth's atmosphere, the Sun, and Earth itself. Because of the great difference in temperature of the two bodies (the Sun's temperature is about $6,000 \mathrm{~K}$; the average terrestrial emission temperature is $255 \mathrm{~K}$ ), they radiate in different portions of the electromagnetic spectrum. See Figure 1. This notion is expressed quantitatively by reference to the wavelengths of the radiation emitted by the bodies. Nearly all the radiation from the Sun appears in the wavelength range 0.2 to $5 \mu \mathrm{m}$. ( $\mu \mathrm{m}$ $=10^{-6}$ meter). Earth's radiation is found in the range 4 to $200 \mu \mathrm{m}$. An equivalent and in some ways more convenient method of describing radiation is to use the reciprocal of the wavelength, called the wave number. In this system, radiation from the Sun falls mostly in the wave-number range 2,000 - 50,000 $\mathrm{cm}^{-1}$ and from the Earth in the range $50-2,500 \mathrm{~cm}^{-1}$. The wave number is the number of waves in one centimeter.

The human eye is sensitive to radiation in only a small part of the spectrum, 0.4 to $0.7 \mu \mathrm{m}$, called the visible spectrum. However, this is the range where the Sun's radiance is at its maximum. Radiation with wavelengths longer than the visible, in the range 0.7 to $600 \mu \mathrm{m}$, is called infrared (IR), or long-wave radiation. Radiation with wavelengths shorter than the visible, in the range 0.15 to $0.4 \mu \mathrm{m}$, is called ultraviolet (UV) radiation. The visible and UV spectra together are referred to as short-wave radiation. Figure 1 shows that radiation from the Sun falls in both the short-wave and long-wave regions, while that from Earth is long-wave only.

Radiation passing through Earth's atmosphere can be absorbed or reflected by constituent gas molecules and aerosols. When a gas molecule absorbs a photon of radiation, its energy increases. Very quickly, the molecule either re-emits the photon in a random direction or shares its energy with another gas molecule through a collision. The latter outcome results in heating the atmosphere.

Absorption of radiation by a gas is specific to narrow ranges or bands of wavelength for particular gas molecules. Any single species of gas absorbs radiation at most in only a fraction of the short-wave or long-wave spectra. The gases that constitute the majority of the atmosphere, nitrogen and oxygen, absorb no long-wave and only a slight amount of short-wave radiation.

The most important atmospheric gas for absorbing radiation in the short-wave spectrum is ozone. Humans recognize it as having a blue color, indicating it is absorbing radiation within the spectral range we are sensitive to. Stratospheric ozone, contained in the outer portion of the atmosphere, intercepts radiation that would otherwise strike the Earth, thus having a cooling effect on Earth. However, it is gases of anthropogenic origin, which absorb long-wave radiation, that are of most interest in the current concern about global climate change. 


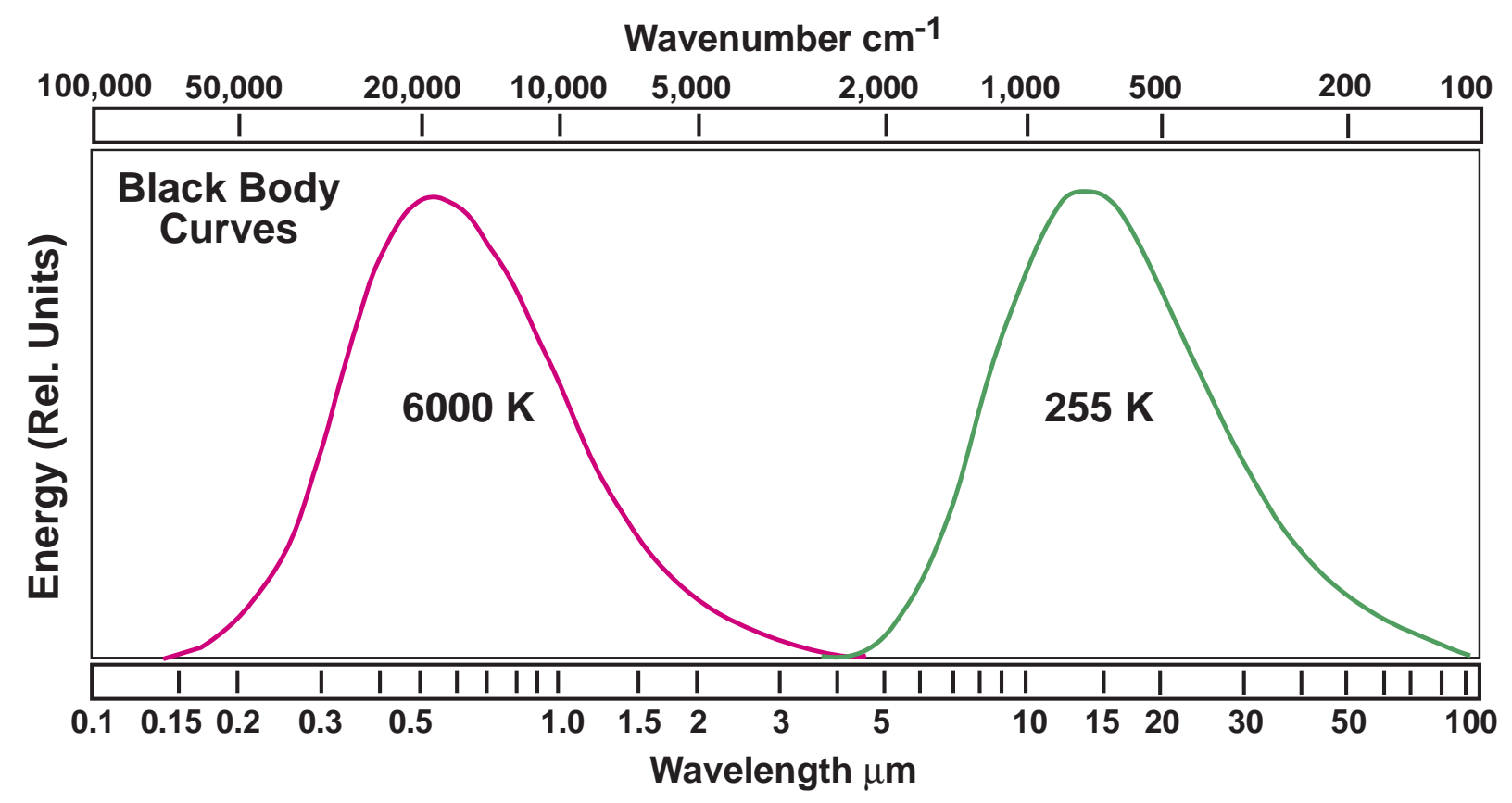

Figure 1. Blackbody Curves for 6,000 K and $255 \mathrm{~K}$ (from Luther and Ellingson 1986)

\section{Atmospheric Warming}

To understand the role of radiation in determining the temperature at Earth's surface, consider the radiation budgets of three parts of the Earth environment: the stratosphere, the troposphere, and the surface itself. The stratosphere is the upper atmosphere, beginning at an altitude of about $13 \mathrm{~km}(8 \mathrm{mi})$ and extending outward to some $50 \mathrm{~km}(30 \mathrm{mi})$ above Earth. As its name indicates, the stratosphere does not turn over or mix. All heat transfer within it is by radiation and conduction by gas molecules colliding. The lower atmosphere, or troposphere, extends from Earth's surface to the bottom of the stratosphere, their boundary being called the tropopause. Turbulent mixing is extensive in the troposphere, and it is an important mechanism for transferring heat from Earth's surface to the tropopause. Both the stratosphere and the troposphere receive radiation from above and from below. Some of this radiation is reflected, some is transmitted, and some is absorbed and re-radiated. Most of the long-wave radiation that passes upward into the stratosphere at the tropopause originates from radiation within the troposphere, rather than from the Earth's surface.

The component of the troposphere that plays the largest role in heat transfer is water. Water is sometimes referred to as a greenhouse gas (GHG), and because of its importance in the heat budget of the atmosphere, some elaboration of its role is worthwhile. Water is unique among atmospheric constituents in that its gas-phase concentration can be reduced by cooling, resulting in the formation of liquid water or ice. Thus, strictly speaking, water in the atmosphere is a vapor, not a gas. The distinction explains why the concentration of gaseous water in the atmosphere is highly variable with position and season. All other greenhouse gases (GHGs) can 
be removed from the atmosphere only by reaction in the atmosphere itself, e.g., oxidation, or by reaction at its boundary, e.g., photosynthesis or absorption in the oceans. Atmospheric fractions of GHGs other than water are nearly constant throughout the atmosphere and change much more slowly than water.

Water plays many roles in the tropospheric thermal budget. It transfers heat upwards by evaporating at Earth's surface, absorbing heat in the process, then condensing to form clouds at altitude, releasing the heat. It forms aerosols, e.g., clouds, that both absorb and reflect radiation, depending on its wavelength. And because aerosols do this with radiation directed both toward Earth and toward space, they act both to increase or decrease the temperature of the troposphere, depending on their altitude and the wavelength of radiation considered. In addition to all this, water vapor molecules absorb radiation like true greenhouse "gases."

Figure 2 gives an idea of how greenhouse gases affect Earth's radiation budget. The irregular line in the figure is the clear sky spectral irradiation at the tropopause measured in summer time at mid latitude. The measurement was taken facing downwards, so the curve shows the radiation upward into the stratosphere. The solid lines show blackbody radiation at several temperatures. The underlying surface temperature was $294 \mathrm{~K}$, about $74{ }^{\circ} \mathrm{F}$. The closer the irregular line to the blackbody curve for $294 \mathrm{~K}$, the more transparent the troposphere to radiation at that wavelength.

Shown above the curves are the portions of the spectrum where water vapor, carbon dioxide $\left(\mathrm{CO}_{2}\right)$, and methane $\left(\mathrm{CH}_{4}\right)$ absorb significantly. The deviation of the measured irradiation from the $294 \mathrm{~K}$ blackbody trace in the wave-number range 0 to $500 \mathrm{~cm}^{-1}$ is caused principally by water vapor. Carbon dioxide is the main absorber in the wave-number range 500 to $800 \mathrm{~cm}^{-1}$. In the tail of the measured spectrum at higher wave numbers, water vapor is again the main absorber.

Note that there is a portion of the spectrum roughly in the wave-number range 800 to $1,200 \mathrm{~cm}^{-1}$ where there is little absorption. In this region, radiation from Earth is able to shine directly to space (the stratosphere is also transparent in this range), essentially unimpeded by the atmosphere. This region is referred to as the atmospheric window for this reason.

The expanded inset in Figure 2 shows the absorbance of $\mathrm{CO}_{2}$ in the vicinity of its major peak at about $670 \mathrm{~cm}^{-1}$. In addition to the central peak, there are multiple smaller absorption bands on either side. Absorption of radiation in the 500 to $800 \mathrm{~cm}^{-1}$ region is dependent on all these bands as well as similar bands from water. All told, in the neighborhood of 100,000 absorption bands from all radiation absorbers in the atmosphere (greenhouse gases) figure in determining the radiation budget of the atmosphere.

We can get a feel for how increasing concentrations of greenhouse gases act to raise Earth's surface temperature, all other things being equal. Each of the atmospheric subsystems, such as the troposphere, is very nearly in thermal equilibrium, receiving and rejecting equal and opposite thermal energy flows. Increasing GHG concentration causes increased atmospheric absorption of radiation in the band width for which a particular greenhouse gas is active. This reduces the amount of radiant energy that escapes upward from the troposphere. To compensate, 
radiant emission from other unaffected parts of the spectrum must increase. The system adjusts by the surface temperature rising slightly, so it becomes a stronger radiation source.

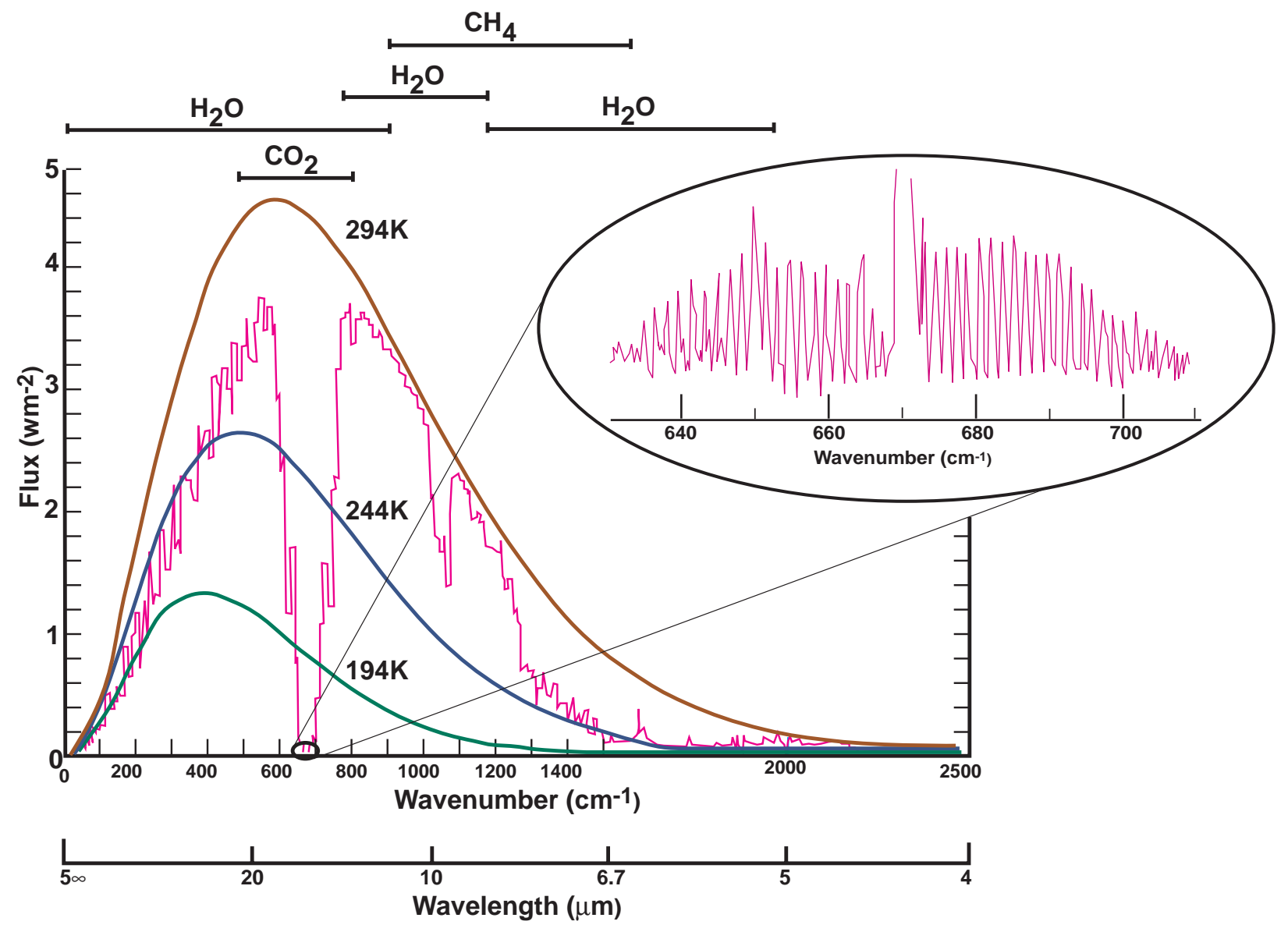

Figure 2. Emission Spectrum at the Tropopause

(from Shine et al. 1990; Luther and Ellingson 1986; and IUPAC 1961)

The smooth lines show the emission from a blackbody $\left(\mathrm{Wm}^{-2}\right.$ per $10 \mathrm{~cm}^{-1}$ spectral interval) across the thermal infrared spectrum for temperatures of $294 \mathrm{~K}, 244 \mathrm{~K}$, and $194 \mathrm{~K}$. The irregular line shows the net flux at the tropopause $\left(\mathrm{Wm}^{-2}\right)$ in each $10 \mathrm{~cm}^{-1}$ interval for a clear-sky mid-latitude summer atmosphere with a surface temperature of $294 \mathrm{~K}$. In general, the closer this line is to the smooth line for $294 \mathrm{~K}$, the more transparent the atmosphere. The inset shows a detailed absorption spectrum for $\mathrm{CO}_{2}$. The bars at the top of the figure indicate regions of significant absorption by water vapor and $\mathrm{CO}_{2}$.

In Figure 2, $\mathrm{CO}_{2}$ is such a strong absorber in the 500 to $800 \mathrm{~cm}^{-1}$ region that one could wonder if it would make any difference to the radiation budget if the $\mathrm{CO}_{2}$ concentration were to increase further. The region of the spectrum it controls is largely closed already to passing radiation upward from the surface. 
In fact it does matter. Increasing concentration widens the band width, increasing absorption at the edges. Also, increasing concentration raises the altitude at which radiation is generated that escapes to the stratosphere within the affected band width. (Upward-directed radiation from $\mathrm{CO}_{2}$ molecules at lower altitude is reabsorbed by $\mathrm{CO}_{2}$ molecules above them.) Temperature decreases with altitude in the troposphere, and the strength of a radiation source (in this case, greenhouse gases) falls with decreasing temperature. The net effect is to reduce the amount of radiation leaving the tropopause within the affected band width. As before, if the energy radiated from Earth in one part of the spectrum is reduced, there must be compensation elsewhere.

We have mentioned the greenhouse gases arising from fossil-fuel use. Methane is released in the mining of coal and in the production and transport of natural gas. Carbon dioxide (together with water) is the main combustion product of fossil-fuel combustion. Nitrous oxide, $\mathrm{N}_{2} \mathrm{O}$, is formed in small amounts in high temperature combustion. Other important greenhouse gases are ozone, which is naturally occurring in the stratosphere and a component of smog in the lower troposphere, and the compounds classed as chlorofluorocarbons (CFCs), and hydrofluorocarbons (HFCs). Both the latter are exclusively anthropogenic in origin.

\section{Potency of Greenhouse Gases}

What are some of the factors that make one greenhouse gas more potent than another?

\section{Atmospheric Concentration}

Water vapor, for example, is present in the troposphere at concentrations many times higher than any other greenhouse gas. In the tropics, where the temperature is high, water can represent up to 4 percent of the atmosphere. The greenhouse gas in next largest amount, $\mathrm{CO}_{2}$, has a concentration of about 365 parts per million, or about 0.04 percent rounded off.

\section{Absorption Strength}

Qualitatively, molecules with asymmetric distribution of electrical charge among their constituent atoms are strong absorbers. This is one reason why CFCs and HFCs are such potent greenhouse gases, containing as they do the highly electronegative chlorine and fluorine atoms.

\section{Average Atmospheric Lifetime}

The longer the atmospheric lifetime of a greenhouse gas, the greater its cumulative effect on radiative forcing. The reason HFCs have replaced CFCs in commerce is that they are more easily oxidized in the atmosphere, shortening their lifetimes relative to the CFCs they replace. Consideration of atmospheric lifetimes also explains why the acid rain precursors, $\mathrm{SO}_{2}$ and $\mathrm{NO}_{\mathrm{X}}$, are not usually considered as greenhouse gases. They wash out of the atmosphere in days or weeks, compared to the lifetimes of years, decades, or centuries for other greenhouse gases. 


\section{Transparency of the Atmosphere at the Wavelengths Where a Particular Gas Absorbs}

Increasing concentrations of a greenhouse gas will always cause increased radiative forcing. However, some portions of the spectrum are more sensitive than others to the presence of GHGs. The atmospheric window described earlier is so nearly transparent that radiative forcing increases directly with concentration for gases that absorb in this region. This is a third reason why CFCs are so potent. Many are active in the wave-number region 800 to $1,200 \mathrm{~cm}^{-1}$. It also helps explain why methane is a stronger greenhouse gas than carbon dioxide. Methane is active within the atmospheric window, while $\mathrm{CO}_{2}$ is not. Climate modelers calculate that $\mathrm{CH}_{4}$ is 21 times more potent than $\mathrm{CO}_{2}$, compared on a molecular basis. Because the portion of the spectrum where $\mathrm{CO}_{2}$ absorbs is already affected by greenhouse gases in the atmosphere, the dependence of additional radiative forcing on increased concentration is weaker for $\mathrm{CO}_{2}$ than for CFCs or $\mathrm{CH}_{4}$.

Through quantitative treatment of these considerations and others, estimates have been made of the extent of additional radiative forcing made by increases in greenhouse gas concentrations that occurred between 1980 and 1990. These are shown in Figure 3. Carbon dioxide accounted for over half the total. This explains the great interest in developing technology that will reduce emissions of $\mathrm{CO}_{2}$, and to a lesser extent, $\mathrm{CH}_{4}$.

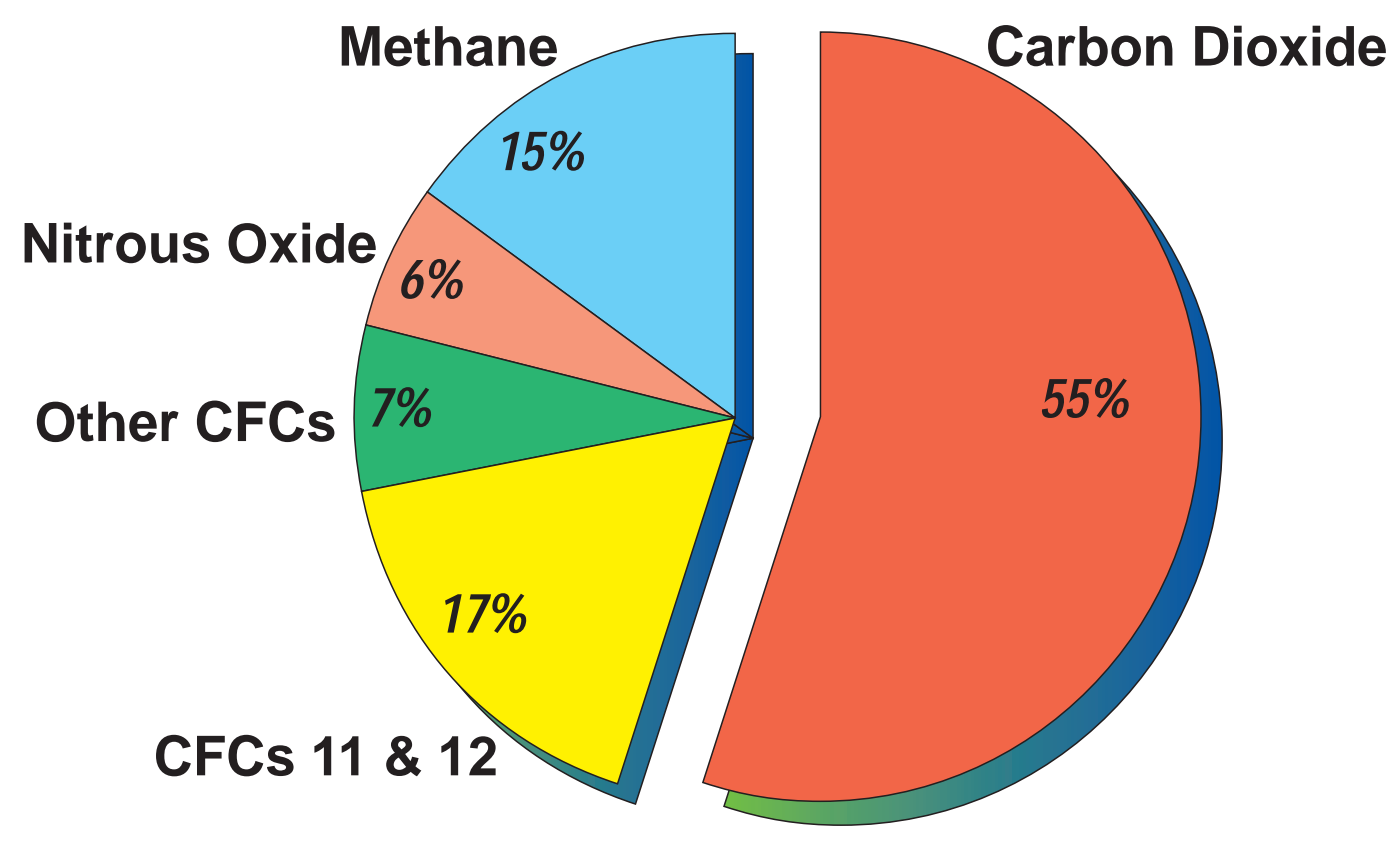

Figure 3. Relative Contributions to Radiative Forcing of Some Greenhouse Gases

(from Houghton et al. 1990) 


\section{Carbon Emissions}

\section{$\mathrm{CO}_{2}$ Emissions Arising From Human Activities}

The Kaya equation helps us focus on ways to reduce emissions of carbon contained in $\mathrm{CO}_{2}$ :

$$
\text { Net } C=\left[\begin{array}{llllll}
G D P & x & E / G D P & x & C g / E
\end{array}\right]-S \text {, }
$$

where Net $\mathrm{C}=$ net carbon emissions,

GDP $=$ gross domestic product,

$\mathrm{E}=$ total energy use,

$\mathrm{Cg}=$ carbon emissions generated $\left(\right.$ as $\left.\mathrm{CO}_{2}\right)$, and

$\mathrm{S}=$ natural and induced sequestration of carbon.

The equation is written this way to show the roles of economic activity, energy efficiency, and the carbon intensity of fuels on net carbon emissions.

The Kaya equation relates the carbon emissions generated while producing goods and services to several terms characterizing the economy and one term for $\mathrm{CO}_{2}$ repositories or sinks. The three terms inside the bracket indicate that emissions rise directly with the GDP, but also depend on terms for the energy intensity of the economy, E/GDP, and the carbon intensity of the energy, $\mathrm{Cg} / \mathrm{E}$.

\section{Energy Intensity of the GDP and Carbon Intensity of Energy}

The principal source of man-made $\mathrm{CO}_{2}$ emissions, especially in developed countries, is consumption of fossil fuels. For strong economic activity (large GDP) to continue while reducing carbon emissions, it is necessary to pay attention to energy intensity for economic output (E/GDP). Also important is the net amount of carbon emitted per unit of energy, the carbon intensity, $\mathrm{Cg} / \mathrm{E}$.

In the period 1986 to 1995 , the energy intensity of the U.S. economy was 16 to 17 megajoules (MJ) per dollar GDP (constant 1987 dollars). Among advanced countries, this was not a good performance. In 1994, the energy intensity for Japan was 7 MJ/dollar, and for 25 advanced industrialized nations including the U.S., it averaged $11 \mathrm{MJ} / \mathrm{dollar}$.

Carbon intensity reflects the character of a particular energy source. Typical values of energy intensity for fossil fuels (expressed in g carbon per MJ, based on the fuel's higher heating value) are shown in Table 1. 
Table 1. Fossil Fuel Energy Intensities

\begin{tabular}{|l|c|}
\hline \multicolumn{1}{|c|}{ Fossil Fuel } & $\begin{array}{c}\text { Energy Intensity } \\
\text { (gC/MJ) }\end{array}$ \\
\hline Coal & $23-26$ \\
\hline Oil & 19 \\
\hline Natural Gas & 13 \\
\hline
\end{tabular}

Renewable energy sources and nuclear energy are considered to have zero carbon intensity because, to an approximation, their use results in no net carbon emissions. For biomass, this assumption requires replanting. The carbon intensity of U.S. energy use at 16 to $17 \mathrm{gC} / \mathrm{MJ}$ for 1988 to 1995 reflects the fact that fossil fuels are the dominant U.S. energy source, representing about 85 percent of all primary energy.

Most people favor keeping the GDP high, even expanding it, so reductions in carbon emissions must be found in the other two terms inside the bracket of the energy equation. The final term, $\mathrm{S}$, represents the $\mathrm{CO}_{2}$ that goes somewhere other than the atmosphere. It can be increased in two ways: by augmenting natural processes that remove $\mathrm{CO}_{2}$ from the atmosphere, such as photosynthesis, or by capturing $\mathrm{CO}_{2}$ at the outlet of a process and storing it in a way that will keep it out of the atmosphere for some appropriate time, generally taken to be centuries or millennia.

FETC has programs that are aimed at decreasing the terms E/GDP and $\mathrm{Cg} / \mathrm{E}$, and increasing the term $\mathrm{S}$. The next section looks at some of the approaches being taken. 


\section{FETC Programs to Reduce Greenhouse Gas Emissions}

\section{Increasing Energy Efficiency (reducing E/GDP)}

Perhaps the most straightforward way of reducing carbon emissions is to increase the efficiency of operations that use carbon-based fuels for heat or power. FETC, as part of the Office of Fossil Energy in the U.S. Department of Energy (DOE), is responsible for developing improved systems to generate electricity from natural gas and coal. Power generation is the principal use made of coal mined in the U.S., and more than half the electricity consumed in the U.S. is generated with coal. About 36 percent of all carbon emissions in the U.S. are caused by electricity production.

Significant increases in generating efficiency have been made in recent years for a number of power systems using both coal and gas. However, because the price of both fuels in the U.S. has been low by world standards, it has been economic for most electric utilities to continue using existing equipment rather than replace it with modern equipment. Thus, the "fleet averages" of both coal and gas electric generating stations in the U.S. is much lower than current state-of-theart equipment. Increasing the thermal efficiency of power generation could substantially reduce U.S. carbon emissions per kilowatt hour $(\mathrm{kWh})$.

The current fleet-average efficiency for all fossil-based electricity generators in the U.S. is about 33 percent. To see the scope for reducing carbon emissions possible with modern power systems, refer to Table 2, which shows the efficiencies for a number of power systems either commercially available now or in advanced states of development. In each case, the indicated efficiency is either attainable today or is the target of a program being pursued by the U.S. DOE. All the power systems listed use multiple power cycles, in contrast to traditional steam, or Rankine, cycles that use just one. Advanced power generation systems also offer other environmental advantages in addition to reduced specific carbon emissions (or kilograms of carbon per megawatt hour, $\mathrm{kg} \mathrm{C} / \mathrm{MWh}$ ).

\section{Decreasing Carbon Intensity of Energy (reducing $\mathrm{Cg} / \mathrm{E}$ )}

\section{Increased Use of Natural Gas for Power Generation}

As noted in a previous section, the carbon intensity of methane, the main constituent of natural gas, is less than that of coal. In addition, natural gas lends itself to high-efficiency power generation cycles that use both combustion turbines and steam, called "combined cycle." The result is that the $\mathrm{kg} \mathrm{C} / \mathrm{MWh}$ from power generated using natural gas are substantially less than for coal. Thus, a straightforward approach to reducing carbon emissions is to increase the use of natural gas in power production. 


\section{Table 2. Thermal Efficiencies of Some Modern Fossil-Based Power Systems \\ (based on higher heating value, HHV, of fuels)}

\begin{tabular}{|l|c|}
\hline \multicolumn{1}{|c|}{ Power System } & $\begin{array}{c}\text { Thermal Efficiency } \\
\text { (percent) }\end{array}$ \\
\hline $\begin{array}{l}\text { Coal: } \\
\text { Integrated Gasification/ Combined Cycle (IGCC) }\end{array}$ & $42-52$ \\
\hline $\begin{array}{l}\text { Coal: } \\
\text { Integrated Gasification/ Fuel Cells (IGFC) }\end{array}$ & $47-64$ \\
\hline $\begin{array}{l}\text { Coal: } \\
\text { High Performance Power Systems (HiPPS) }\end{array}$ & $51-54$ \\
\hline $\begin{array}{l}\text { Coal: } \\
\text { Pressurized Fluidized Bed (PFB) }\end{array}$ & $42-50$ \\
\hline $\begin{array}{l}\text { Natural Gas: } \\
\text { Combustion Turbine/Steam Turbine Combined Cycle }\end{array}$ & $55-60$ \\
\hline $\begin{array}{l}\text { Natural Gas: } \\
\text { Fuel Cell/Combustion Turbine Combined Cycle }\end{array}$ & $65-67$ \\
\hline
\end{tabular}

Of course, things are never so simple. Before electricity generators commit to a large increase in gas use, questions of price and resource availability have to be answered. Natural gas is more expensive than coal on a calorific basis. As well, there is uncertainty whether reserves of natural gas and the ability to produce it are sufficient to permit a large increase in its use at a stable price.

To address these problems, FETC is implementing a DOE program aimed at increasing reserves and production of gas. The program has two components: one near term, one visionary. Near-term, the goal is to increase domestic gas consumption from 22 trillion cubic feet (Tcf) reached in 1995, to $28 \mathrm{Tcf}$ by the year 2010, an increase of 27 percent. This will be achieved by a comprehensive program directed at conventional gas resources, so-called "tight" sands (those with low permeability), and coalbed methane. Improvements are expected in the areas of drilling and completion, well stimulation, exploration, and description of reserves (using seismic imaging and resource diagnostics).

The visionary component of the program is directed at recovering natural gas from hydrates. Gas hydrates are solids resembling ice that consist of natural gas and water. Their stability depends on both temperature and pressure, but at the elevated pressures where they are found, in the deep underground or under the ocean, the hydrates are stable at temperatures above 
the freezing point of water. Hydrates are found principally in arctic regions and under the ocean floor, where the temperature is only a few degrees above zero celsius. Resources of natural gas hydrates are imprecisely known, but are generally accepted as being huge compared to more conventional sources - perhaps as high as hundreds of millions of Tcf. If technology can be developed that will permit production of gas from hydrates, it will change the way the world uses fossil fuels.

\section{Co-Firing Biomass and Coal}

Biomass (e.g., wood, sawdust, alfalfa stems) is considered to have a net carbon intensity of zero when it is used for generation of heat or power, where it is reasonable to neglect the energy used to grow it and collect it. The idea is that the carbon it contains was drawn out of the atmosphere during photosynthesis, so returning it to the atmosphere during combustion involves no net addition.

FETC has a number of cooperative projects underway with national laboratories that are funded by DOE, private industry, and the Electric Power and Research Institute (EPRI) to study co-firing coal and biomass. There are a number of reasons why co-firing coal and biomass may be preferable to burning biomass by itself. One reason is that because biomass has a lower energy density (e.g., joule/g) than fossil fuels, it is often difficult to maintain the desired boiler temperature when firing biomass by itself. Another reason is that in many locations, insufficient biomass is available for it to generate all the steam required by itself. However, it could still supplement existing fossil-fuel boilers. The cooperative programs are being carried out in equipment that ranges from laboratory bench top, to pilot plant, to utility scale boilers. Preparing biomass for combustion, and combusting it, have important differences compared to the use of coal. The experimental programs are gathering data that will reveal the near-term potential of biomass for heat and power generation.

\section{Production of Liquid Hydrocarbon Fuels From Remote Natural Gas}

DOE, with technical supervision by FETC, has sponsored R\&D to develop an improved method for separating oxygen from air. The method uses a selectively permeable ceramic membrane called an Ionic Transport Membrane (ITM). Compared to the dominant current technology for preparing oxygen, which uses cryogenics, the ITM offers reduced capital and operating costs. One application of ITM has particular potential for developing technologies to reduce $\mathrm{CO}_{2}$ emissions by providing a new route to a premium liquid fuel. The ITM is used as a component of a catalytic approach to producing synthesis gas (a mixture of carbon monoxide and hydrogen) from natural gas and oxygen. Syngas can be converted to distillate liquid hydrocarbons by a well understood process called Fisher-Tropsch synthesis. The current industrial method for making syngas from natural gas uses steam cracking. Use of the ITM catalytic approach provides higher yields and an anticipated reduction in capital cost for syngas production of at least 20 percent compared to existing technology. 
These advances appear to open the way for commercial development of so-called remote natural gas, i.e., reserves that are not currently economic to develop via pipeline access to users. Examples of such reserves are found far off shore in the ocean and in the arctic. Remote gas that is converted to liquid fuels on site can be transported to markets more economically than can the raw gas. Carbon emission reduction would be achieved compared to use of coal for power generation because of the reduced carbon intensity of the fuel and the direct use of combustion turbines in combined cycles.

\section{Increasing $S$ (enhancing natural sinks and creating synthetic sinks)}

\section{Deep Subterranean Injection of $\mathrm{CO}_{2}$}

One approach to avoiding venting of $\mathrm{CO}_{2}$ into the atmosphere is to collect it at the point of its generation, e.g., the stack of a fossil-power plant, pressurize it, and then transfer it by pipeline to a subterranean formation where it will remain for an extended period, at least several hundred years.

Candidate land-based subterranean repositories or reservoirs must satisfy a number of criteria. There must be no possibility of a sudden discharge of a large amount of $\mathrm{CO}_{2}$. The reservoir must have a substantial capacity. The sum of all costs associated with transportation and injection of the $\mathrm{CO}_{2}$ from the point of collection to the repository must be competitive with other possible approaches for reducing carbon emissions.

Two kinds of reservoirs being studied at FETC are depleted oil and gas fields, and deep subterranean saline aquifers. Depleted oil and gas fields are natural candidates, as it is known that they would have both capacity and integrity (absence of leaks). Deep subterranean aquifers, as a class, are thought to have a larger capacity than depleted oil and gas fields and are expected to be more geographically accessible to most large $\mathrm{CO}_{2}$ generation sources. The $\mathrm{CO}_{2}$ would dissolve in the water under the extremely high pressures that would be used. Deep aquifers have been approved by EPA for disposal of toxic-waste liquids, which suggests they possess good characteristics of stability and integrity. FETC is sponsoring studies into the suitability of both types of reservoir for sequestering $\mathrm{CO}_{2}$.

\section{Injection of $\mathrm{CO}_{2}$ Into Deep Coal Seams}

An approach for $\mathrm{CO}_{2}$ sequestration with double appeal is to inject it into deep coal seams. Methane is a coproduct with coal of the transformation process that converts biomass to coal during coalification. All unmined coals contain some methane, the amount generally increasing with the rank of the coal and its depth. It has been found that $\mathrm{CO}_{2}$ can be injected into underground coal with the effect of displacing methane. The affinity of coal for $\mathrm{CO}_{2}$ is greater than that for $\mathrm{CH}_{4}$, so approximately two volumes of $\mathrm{CO}_{2}$ can be sequestered in coal while displacing one volume of $\mathrm{CH}_{4}$, which can be collected. Both $\mathrm{CO}_{2}$ and $\mathrm{CH}_{4}$ would be transported into and out of the coal seam through the piping used in gas wells. 
The potential volumes of carbon dioxide that could be sequestered and methane that could be recovered in this way are extremely large. While total U.S. coal resources are extensive about 4 trillion tonnes - only about 7 percent are economically recoverable at present prices. This means that prospects are remote for mining much of the coal, especially the deepest seams. If $\mathrm{CO}_{2}$ were injected into such deep seams, the coal would likely be left undisturbed, providing permanent disposal of the $\mathrm{CO}_{2}$. The methane that is potentially recoverable from 16 coal basins in the U.S. is estimated at $400 \mathrm{Tcf}$.

Use of $\mathrm{CO}_{2}$ to increase production of natural gas from coal seams is being tested for commercial use by a Houston energy company, Burlington Resources, Inc. DOE, represented by FETC, is conducting a cooperative research program with the Canadian province, Alberta, to determine the reservoir engineering practices needed to employ the technique most effectively for both methane recovery and $\mathrm{CO}_{2}$ sequestration.

\section{Deep Sea Injection of $\mathrm{CO}_{2}$}

Another potential reservoir for storing $\mathrm{CO}_{2}$ is direct injection into the deep ocean. The ocean is already the destination for most of the $\mathrm{CO}_{2}$ generated by human activities. If direct injection were used, $\mathrm{CO}_{2}$ in a concentrated form would be sent to the deep ocean rather than absorbed from the atmosphere at the ocean surface as is now the case. The capacity of the ocean for holding $\mathrm{CO}_{2}$ is vast. Deep waters of the ocean already hold about 50 times more $\mathrm{CO}_{2}$ than the atmosphere, and several times more than all known resources of organic carbon (oil, gas, coal, etc.). It is estimated that the water in deep ocean trenches takes about 1,000 years to cycle to the surface. Carbon dioxide injected in such trenches would stay out of the atmosphere for that length of time.

To place $\mathrm{CO}_{2}$ in the deep ocean, pipelines extending from the shore or extending downward from large tanker ships would likely be used. Most plans envisage transporting liquid $\mathrm{CO}_{2}$, at elevated pressure but ambient temperature, to the location for deep injection. Because $\mathrm{CO}_{2}$ is compressible, it becomes more dense than seawater at a depth of about 3,000 $\mathrm{m}$ because of water pressure. Carbon dioxide released in the ocean at this depth or greater would tend to sink rather than rise. Not all injection approaches being considered would release the $\mathrm{CO}_{2}$ at such a great depth. Once in the ocean, $\mathrm{CO}_{2}$ that had been deeply injected would dissolve in the water in a similar manner to $\mathrm{CO}_{2}$ that enters the ocean in the conventional manner, although the rate of dissolution cannot yet be predicted with confidence.

Before $\mathrm{CO}_{2}$ could be injected in the deep oceans on a large scale, questions in a number of fields - international law, ecology, and ocean engineering, to name a few - have to be answered. To start to get information needed to evaluate the concept of deep ocean injection, DOE is participating in a pilot project that will be carried out off the coast of Hawaii. Other nations taking part in the project are Norway and Japan. Plans call for injection testing to begin in about 2 years.

In related work, FETC is conducting in-house research to gain a better understanding of how droplets of liquid $\mathrm{CO}_{2}$ behave under conditions that prevail in the deep oceans. 


\section{Retrofitting Existing Coal-Fired Boilers for Use of Oxygen Instead of Air}

"Collection" is one of the major components of total cost for a system that collects, transports, and sequesters $\mathrm{CO}_{2}$ in a permanent reservoir. In the case of conventional coal-fired power plants, if collection were desired, the $\mathrm{CO}_{2}$ would be absorbed in a large piece of equipment prior to passing the remaining gas up the stack. The single largest component of flue gas is the nitrogen associated with combustion air. If this nitrogen could be avoided altogether by using oxygen instead of air for combustion, both the capital and operating costs of collection would be materially reduced. Some new power cycles are being designed to use oxygen instead of air. However, the existing stock of coal-fired boilers was designed for use of air, and simply switching from air to oxygen is not possible. The resultant increase in temperature inside the boiler if such a switch were made would rapidly destroy it.

However, if part of the flue gas from a boiler being fed with oxygen is recycled to the boiler, then an unreactive diluent, similar to nitrogen, would moderate combustion in the boiler. This approach is being investigated in a pilot-scale boiler at a Government of Canada laboratory in Ottawa, and FETC is participating in this testing program. Results of the program should indicate if retrofitting boilers to operate with oxygen is feasible, and if so, whether this means lower system costs for $\mathrm{CO}_{2}$ collection.

\section{Coal Mine Methane Capture and Use}

Unmined coal lying undisturbed underground has varying amounts of methane within it. When the coal is mined, the methane is released. If no provision is made to capture the methane, it vents into the atmosphere. Worldwide, this is a major source of anthropogenic methane emission to the atmosphere, estimated to be in the neighborhood of 20 to 30 percent of the total. Depending on the rank of the coal being mined and its depth, associated methane can have an energy content equal to several percent of that of the coal in which it is held.

Workers at FETC have helped develop technology to capture and use for heat or power generation the methane that would otherwise be vented to the atmosphere. A number of approaches are possible: collection of the methane before mining by sinking gas wells into the coal seams from above ground; drilling into coal seams during mining operations but prior to removing particular sections of coal; and capture of methane by wells drilled into the rubble created during longwall mining. Capturing methane in one of these ways rather than sweeping it out of the mine with ventilation air offers a number of benefits. Productivity and safety within the mine are enhanced. Injection of methane, a potent greenhouse gas, into the atmosphere is avoided. And beneficial use is made of the methane.

\section{Engineering Data Base for Collection, Transportation, and Sequestration of $\mathrm{CO}_{2}$}

FETC is developing an engineering data base for information on capture, transportation, and sequestration $(\mathrm{C} / \mathrm{T} / \mathrm{S})$ of $\mathrm{CO}_{2}$. A substantial body of literature already exists on $\mathrm{C} / \mathrm{T} / \mathrm{S}$, much of it funded by the International Energy Agency, of which the USA is a member state, and also 
funded by DOE. One function of the $\mathrm{C} / \mathrm{T} / \mathrm{S}$ data base is to collect and provide access to this growing body of literature. Another function is to use this literature, and supplement it where necessary, to develop technical, economic, and logistics data for the suite of C/T/S technology options. This capability is desired for various fossil-based power systems and locations. An anticipated use of the data base is to assist calculations of the extent to which $\mathrm{CO}_{2}$ sequestration could be practiced, and the cost, at particular locations.

Serious work to devise the technologies to permit continued access by society to the benefits of electricity generation and transportation fuels from fossil resources with reduced emissions of $\mathrm{CO}_{2}$ and $\mathrm{CH}_{4}$ is only now beginning in earnest. Time will reveal which approaches yield the greatest emission reductions most cost effectively. It is fortunate that we are starting this new chapter of fossil energy technology with many promising approaches to pursue. 


\section{References}

Houghton, J.T., G.J. Jenkins, and J.J. Ephraums, eds, 1990, Summary Chapter, Climate Change, The IPCC Scientific Assessment, Cambridge: University Press.

International Union of Pure and Applied Chemistry (IUPAC), 1961, Tables of Wave Numbers for the Calibration of Infra-red Spectrometers, Washington: Butterworth.

Luther, F.M., and R.G. Ellingson, 1986, Chapter 2, Projecting the Climatic Effects of Increasing Carbon Dioxide, U.S. Government Printing Office 1986-491-177:30137.

Shine, K.P., R.G. Derwent, D.J. Wuebbles, and J-J. Morcrette, 1990, Chapter 2, Climate Change, The IPCC Scientific Assessment (J.T. Houghton, G.J. Jenkins, and J.J. Ephraums, eds), Cambridge: University Press. 